\title{
Studies on Physico Chemical Properties of Soil in Tree Arboretum of UAS GKVK Bengaluru, Karnataka, India
}

\author{
K. L. Ramyashree ${ }^{1}$, S. C. Kiran ${ }^{2 *}$ and C. Nagarajaiah ${ }^{2}$ \\ ${ }^{1}$ Department of Environmental Science UAS GKVK Bengaluru, India \\ ${ }^{2}$ Department of Forestry and Environmental Science UAS GKVK Bengaluru, India
}

*Corresponding author

\begin{tabular}{|l|}
\hline K e y w o r d s \\
$\begin{array}{l}\text { Productivity, } \\
\text { growth, forest, } \\
\text { laterite soils }\end{array}$ \\
\hline Article Info \\
\hline $\begin{array}{l}\text { Accepted: } \\
\text { 15 August } 2019 \\
\text { Available Online: } \\
10 \text { September } 2019\end{array}$ \\
\hline
\end{tabular}

A B S T R A C T

The study entitled "Studies on physico chemical properties of soil in tree arboretum of UAS GKVK Bengaluru" was carried out in 30-year-old plantation at tree arboretum UAS GKVK Bengaluru with majorly found tree species such as Ceiba pentandra, Artocarpus hirsutus, Grevillea robusta and Sterculia companulata. The results revealed that at different depth $(0-15$ and $15-30 \mathrm{~cm})$ of soil among the different tree species maximum available Nitrogen $(287.31 \mathrm{~kg} / \mathrm{ha})(270.95 \mathrm{~kg} / \mathrm{ha})$, Potassium $(109.3 \mathrm{~kg} / \mathrm{ha})(96.0 \mathrm{~kg} / \mathrm{ha})$ and soil moisture $(12.02 \%)(12.9 \%)$ was found highest in Ceiba pentandra at depth of $0-15 \mathrm{~cm}$ and $15-30 \mathrm{~cm}$ respectively. Artocarpus hirsutus showed higher amount of Phosphorous $(40.74 \mathrm{~kg} / \mathrm{ha})$ $(24.1 \mathrm{~kg} / \mathrm{ha})$ content, Electrical conductivity $(0.20 \mathrm{ds} / \mathrm{m})(0.19 \mathrm{ds} / \mathrm{m})$ and Organic carbon $(2.38 \%)(2.25 \%)$ and Sterculia companulata has higher bulk density $(1.14 \mathrm{~g} / \mathrm{cm} 3)(1.6 \mathrm{~g} / \mathrm{cm} 3)$ at depth of $0-15 \mathrm{~cm}$ and $15-30 \mathrm{~cm}$ respectively. Hence Ceiba pentandra and Artocarpus hirsutusare the tree species which improves the soil quality and maintains the soil in an sustainable way.

\section{Introduction}

The Arboretum UAS GKVK (Bengaluru) was established in the year 1987 by the Department of Forestry with the main goal to establish a social forest and the best use of wasteland. Introduction of species involves adaptation, productivity and success in new types of environmental conditions but these there tree species are indigenous to India and they are more vigorous in adaptation in general, each plant species has specific requirements for the soil-ecological environment. If plants are to grow to their potential, they must be provided by a satisfactory soil environment. On the other hand, inappropriate conditions may limit or 
even make it impossible to grow a given plant species. Tree growth requires adequate availability of water and oxygen from the soil as well as a sufficient supply of nutrients, light and heat (Wall and Heiskanen, 2009). Many works define mainly physical and chemical of soil properties affecting plants growth. The physical properties are considerably undervalued, even though excessively wet or dry, shallow or impermeable soils can severely limit or even interrupt the growth of plants (Huxley et al., 1992). For the favourable course of biological processes as well as the life of soil organisms and plant roots, it is important to provide a sufficient supply of water and air into the soil. On the base of soil moisture monitoring, which is carried out it can be stated that in the recent years there were significant changes in the dynamics of soil moisture, available water supplies and soil moisture stratification. In contrast to laterite soils, poor moisture conditions are in the lowest forest zones, in the areas where the output of water significantly exceeds atmospheric precipitation, and the ability of soil to provide enough utilizable water usually covers only for some days. Unfavourable moisture is one of the main causes of deteriorating soil environment with a tendency of physiological weakening and even necrosis of trees (Tužinský, 2007). Soil moisture not only affects physical, chemical and biological soil properties, but it is also essential for plant growth. The amount of soil water used by plant varies depending on characteristics of soil e.g., texture and plant e.g., roots distribution, depth and transpiration coefficient (Hosseinia et al., 2016). Since favourable rooting space, an abundance of nutrients, water and appropriate air exchange in the soil are important conditions for right tree life, the study aimed to find out which Physico-chemical properties of soil promote or limit the vitality among the four tree species introduced.

\section{Materials and Methods}

A present study was conducted in tree arboretum UAS, GKVK. Bengaluru established in 1987, geographically, the place is located at $13^{0} 05^{\prime \prime} \mathrm{N}$ latitude and $77^{0} 34^{\prime \prime} \mathrm{E}$ longitude. The centre is at an altitude of 924 meters above mean sea level. The annual rainfall ranges from $528 \mathrm{~mm}$ to $1374.4 \mathrm{~mm}$ with the mean of $915.8 \mathrm{~mm}$. Tree species identified are indigenousnamely Ceiba pentandra, Artocarpus hirsutus, Grevillea robusta and Sterculia campanulata. of thirty years of age and planted with $2 \mathrm{~m} \times 2$ mspacing.The soil samples were collected from the tree arboretum up to depth of 0-15 $\mathrm{cm}$ and $15-30 \mathrm{~cm}$ layer of the top soil from each tree species for soil analysis. At each sampling point, 8 samples were collected (4 tree species $\times 3$ replications). Thus a total 24 soil samples were collected and analysed for physico chemical properties such as soil moisture, Bulk density, soil $\mathrm{pH}$, organic carbon, electrical conductivity, available nitrogen, available phosphorus, and exchangeable potassium using standard procedures like Soil moisture content was determined by weight loss after drying fresh soil at $100-110^{\circ} \mathrm{C}$ for 24 hours using a formula.

Soil moisture content (\%)

$=$ Wet soil (g) - Oven Dry soil (g) Oven Dry soil (g) x 100

Oven Dry soil $(\mathrm{g})$

Bulk density of were done using a steel cylinder (Jackson, 1958). Bulk density was estimated by taking out a core of undisturbed soil by using steel cylinder. The soil was dried and weighed.

The volume of soil was calculated by measuring the volume of cylinder $(\pi \mathrm{r} 2 \mathrm{~h})$. The bulk density was calculated by dividing the oven dry weight of samples ( $\mathrm{g}$ ) by volume of the soil. 
The methodology fallowed for soil analysis

\begin{tabular}{|c|c|c|}
\hline Particulars & Methodology adopted & Reference \\
\hline $\mathbf{p H}$ & $\begin{array}{l}\text { 1:2.5 soil water suspension with the help of digital } \mathrm{pH} \\
\text { meter }\end{array}$ & Jackson (1973) \\
\hline $\mathrm{EC}(\mathrm{ds} / \mathrm{m})$ & $\begin{array}{l}1: 2.5 \text { soil water suspension using } \\
\text { conductivity bridge }\end{array}$ & Jackson (1973) \\
\hline Organic Carbon $(\%)$ & Walkley and Black rapid titration method & $\begin{array}{l}\text { Walkley and } \\
\text { Black (1934) }\end{array}$ \\
\hline Available $\mathbf{N}\left(\mathrm{kg} \mathrm{ha}^{-1}\right)$ & Alkaline potassium permanganate method & $\begin{array}{l}\text { Subbiah and Asija } \\
\qquad(\mathbf{1 9 5 6 )}\end{array}$ \\
\hline $\begin{array}{l}\text { Available } \mathrm{P}_{205} \\
\qquad\left(\mathrm{~kg} \mathrm{ha}^{-1}\right)\end{array}$ & $\begin{array}{l}\text { Spectrophotometric (Olsen Extraction method with } \\
0.5 \mathrm{M} \mathrm{NaHCO} 3)\end{array}$ & Jackson (1973) \\
\hline $\begin{array}{l}\text { Available K2O } \\
\qquad\left(\mathrm{kg} \mathrm{ha}^{-1}\right)\end{array}$ & $\begin{array}{c}\text { Flame photometric (Extraction with N NH4OAc } \\
\text { of pH 7) }\end{array}$ & Jackson (1973) \\
\hline
\end{tabular}

\section{Results and Discussion}

\section{Soil moisture and Bulk density}

Soil moisture is an important component and key mediator between land surface and atmospheric interactions and the observations can be seen that, soil moisture in the deeper layer having high moisture.

The higher soil moisture content was noticed in Ceiba pentandra $(12.02 \%)$ and $(12.9 \%)$ at the depth of $0-15 \mathrm{~cm}$ and $15-30 \mathrm{~cm}$ respectively followed by A. hirsutus $(8.04 \%)$ and $(9.86 \%)$, Grevillea robusta (7.20) and (8.90) and lowest moisture content in Sterculia companulata (7.06) and (8.80). The bulk density of soil calculated from the undisturbed soil cores collected from the field under different tree species revealed that bulk density shows a direct relationship with increase in depth of soil and maximum bulk density observed in Sterculia companulata $\left(1.14 \mathrm{~g} / \mathrm{cm}^{3}\right)$ and $(1.6 \mathrm{~g} / \mathrm{cm} 3)$ with depths $0-15$ $\mathrm{cm}$ and $15-30 \mathrm{~cm}$ respectively followed by Grevillea robusta $\left(1.07 \mathrm{~g} / \mathrm{cm}^{3}\right)$ and $\left(1.35 \mathrm{~g} / \mathrm{cm}^{3}\right)$, Artocarpus hirsutus $\left(1.07 \mathrm{~g} / \mathrm{cm}^{3}\right)$ and $\left(1.21 \mathrm{~g} / \mathrm{cm}^{3}\right)$ and the minimum in Ceiba pentandra $\left(1.06 \mathrm{~g} / \mathrm{cm}^{3}\right)$ and $\left(1.1 \mathrm{~g} / \mathrm{cm}^{3}\right)$ which is ideal for better plant growth.

\section{Soil pH, Electrical conductivity and Organic Carbon}

The maximum $\mathrm{pH}$ observed in Ceiba pentandra (6.45) and (6.2) followed by Artocarpus hirsutus (6.03) and (5.9), Sterculia campanulata (5.78) and (5.70) and the minimum in Grevillea robusta (5.60) and (5.45) with the depth $10-15 \mathrm{~cm}$ and $15-30 \mathrm{~cm}$ respectively,but Electrical conductivity was found significantly higher in Artocarpus hirsutus $(0.20 \mathrm{ds} / \mathrm{m})$ and $(0.19 \mathrm{ds} / \mathrm{m})$ than the remaining tree species i.e., followed by Grevillea robusta $(0.19 \mathrm{ds} / \mathrm{m})$ and $(0.19 \mathrm{ds} / \mathrm{m})$, Ceiba pentandra $(0.18 \mathrm{ds} / \mathrm{m})$ and $(0.17 \mathrm{ds} / \mathrm{m})$ a Sterculia companulata $(0.17 \mathrm{ds} / \mathrm{m})$ ) and $(0.16 \mathrm{ds} / \mathrm{m})$ with respect to depth $0-15 \mathrm{~cm}$ and $15-30 \mathrm{~cm}$. The decrease in soil $\mathrm{pH}$ and EC under tree cover and increase in soil nutrient and organic carbon content was also observed. Soil organic carbon content was found significantly higher in Artocarpus hirsutus $(2.38 \%)$ and $(2.25 \%)$ followed by 
Ceiba pentandra (1.59\%) and (1.36\%), Grevillea robusta $(1.65 \%)$ and $(1.52 \%)$ and Sterculia companulata (1.33\%) and (1.20\%) with respect to depth $0-15 \mathrm{~cm}$ and $15-30 \mathrm{~cm}$. The SOC content in all the depth, varied significantly and it followed an inverse relation with increase in depth.

\section{NPK status}

available nitrogen at $0-15 \mathrm{~cm}$ and $15-30 \mathrm{~cm}$ depth under four different tree species likein Ceiba pentandra $(287.31 \mathrm{~kg} / \mathrm{ha})$ and $(270.95$ $\mathrm{kg} / \mathrm{ha}$ ) was significantly higher than the remaining trees followed by A.hirsutus $(252.78 \mathrm{~kg} / \mathrm{ha})$ and $(240.95 \mathrm{~kg} / \mathrm{ha})$, Sterculia companulata $(270.95 \mathrm{~kg} / \mathrm{ha})$ and $(270.95$ $\mathrm{kg} / \mathrm{ha}$ ) and lowest value observed in Grevillea robusta $(194.01 \mathrm{~kg} / \mathrm{ha})$ and $(180.63 \mathrm{~kg} / \mathrm{ha})$ and the similar pattern was observed in a exchangeable potassium except the Sterculia componata is replaced by Grevillea robusta. When coming to available phosphorous Artocarpus hirsutus $(40.74 \mathrm{~kg} / \mathrm{ha})$ and $(24.1$ $\mathrm{kg} / \mathrm{ha}$ ) was significantly higher followed by Ceiba pentandra $(25.95 \mathrm{~kg} / \mathrm{ha})$ and (21.0 $\mathrm{kg} / \mathrm{ha})$, Sterculia companulata $(20.83 \mathrm{~kg} / \mathrm{ha})$ and $(15.04 \mathrm{~kg} / \mathrm{ha})$ and Grevillea robusta $(16.01 \mathrm{~kg} / \mathrm{ha})$ and $(12.36 \mathrm{~kg} / \mathrm{ha})$ with respect to depth $0-15 \mathrm{~cm}$ and $15-30 \mathrm{~cm}$ wer e noticed. The tree arboretum established in 1987 has changed the physico chemical nature of soil and the land which was converted in to productive and become a rich in soil nutrients, specifically the tree species Ceiba pentandraand Artocarpus hirsutus were the game changer in all respect of soil physicochemical alteration in a positive manner.

Table.1. Soil moisture and Bulk density $(\mathrm{g} / \mathrm{cm} 3)$ of soil under four different tree species of 30-years tree arboretum at UAS GKVK

\begin{tabular}{|c|l|l|l|l|l|}
\hline & & \multicolumn{3}{|c|}{ Soil Moisture } & \multicolumn{2}{c|}{ Bulk Density } \\
\hline $\begin{array}{r}\text { SI. } \\
\text { No. }\end{array}$ & Tree species & $\mathbf{0 - 1 5} \mathbf{c m}$ & $\mathbf{1 5 - 3 0} \mathbf{c m}$ & $\mathbf{0 - 1 5} \mathbf{c m}$ & $\mathbf{1 5 - 3 0} \mathbf{c m}$ \\
\hline $\mathbf{1}$ & Ceiba pentandra & $12.02 \mathrm{a}$ & $12.9 \mathrm{a}$ & $1.06 \mathrm{c}$ & $\mathbf{1 . 1 0 c}$ \\
\hline $\mathbf{2}$ & Artocarpus hirsutus & $8.04 \mathrm{~b}$ & $9.86 \mathrm{~b}$ & $1.07 \mathrm{~b}$ & $\mathbf{1 . 2 1 c}$ \\
\hline $\mathbf{3}$ & Grevillea robusta & $7.20 \mathrm{c}$ & $8.90 \mathrm{c}$ & $1.07 \mathrm{~b}$ & $\mathbf{1 . 3 5 b}$ \\
\hline $\mathbf{4}$ & Sterculia companulata & $7.06 \mathrm{c}$ & $8.80 \mathrm{c}$ & $1.14 \mathrm{a}$ & $\mathbf{1 . 6 0 a}$ \\
\hline & F significance & $*$ & $*$ & $*$ & $*$ \\
\hline & Tree species (SEm) & 0.8 & 0.8 & 0.03 & $\mathbf{0 . 0 3}$ \\
\hline & Depth (SEm) & 0.4 & 0.4 & 0.01 & $\mathbf{0 . 0 1}$ \\
\hline & CD & 0.21 & 0.21 & 0.03 & $\mathbf{0 . 0 5}$ \\
\hline & CV & $\mathbf{2 . 3}$ & $\mathbf{2 . 3}$ & $\mathbf{4 . 1}$ & $\mathbf{4 . 1}$ \\
\hline
\end{tabular}

*Significance at $5 \%$

Values in the parenthesis are standard deviation of the mean.

Values followed by same superscript in a column do not differ significantly (LSD, P, 0.05) 
Table.2 Soil pH and Electrical conductivity (ds/m)of soil under four different tree species of 30years tree arboretum at UAS GKVK

\begin{tabular}{|c|c|c|c|c|c|}
\hline & & \multicolumn{2}{|c|}{ soil pH } & \multicolumn{2}{|c|}{ Electrical conductivity $(\mathrm{ds} / \mathrm{m})$} \\
\hline SI.No. & Tree species & $0-15 \mathrm{~cm}$ & $15-30 \mathrm{~cm}$ & $0-15 \mathrm{~cm}$ & $15-30 \mathrm{~cm}$ \\
\hline 1 & Ceiba pentandra & $6.45^{\mathrm{a}}$ & $6.20^{\mathrm{a}}$ & $0.18^{\mathrm{bc}}$ & $\begin{array}{c}0.17^{\mathrm{a}} \\
\text { b }\end{array}$ \\
\hline 2 & Artocarpus hirsutus & $6.03^{b}$ & $5.90^{\mathrm{b}}$ & $0.20^{\mathrm{a}}$ & $0.19^{\mathrm{a}}$ \\
\hline 3 & Grevillea robusta & $5.60^{\mathrm{c}}$ & $5.45^{\mathrm{c}}$ & $0.19^{\mathrm{ab}}$ & $0.19^{\mathrm{a}}$ \\
\hline 4 & Sterculia companulata & $5.78^{\mathrm{c}}$ & $5.70^{\mathrm{b}}$ & $0.17^{\mathrm{c}}$ & $0.16^{b c}$ \\
\hline & F significance & & $*$ & $*$ & $*$ \\
\hline & Tree species(SEm) & 0.16 & 0.16 & 0.07 & 0.07 \\
\hline & Depth (SEm) & 0.32 & 0.32 & 0.15 & 0.15 \\
\hline & $\mathrm{CD}$ & 0.30 & 0.21 & 0.01 & 0.01 \\
\hline & CV & 4.1 & 4.1 & 15.98 & 15.98 \\
\hline
\end{tabular}

*Significance at 5\%

Values in the parenthesis are standard deviation of the mean.

Values followed by same superscript in a column do not differ significantly (LSD, P, 0.05) 
Table.3: NPK status at different depths of soil under different major tree species in tree arboretum.

\begin{tabular}{|c|c|c|c|c|c|c|c|c|c|}
\hline \multirow[b]{2}{*}{$\begin{array}{l}\text { Sl. } \\
\text { No. }\end{array}$} & \multirow[b]{2}{*}{ Tree species } & \multicolumn{2}{|c|}{$\begin{array}{c}\text { Organic Carbon } \\
\%\end{array}$} & \multicolumn{2}{|c|}{$\begin{array}{c}\text { Available Nitrogen } \\
\text { (kg ha-1) }\end{array}$} & \multicolumn{2}{|c|}{$\begin{array}{l}\text { Available phosphorous } \\
\qquad\left(\mathrm{kg} \mathrm{ha}^{-1}\right)\end{array}$} & \multicolumn{2}{|c|}{$\begin{array}{l}\text { Exchangeable potassium } \\
\qquad\left(\mathrm{kg} \mathrm{ha}^{-1}\right)\end{array}$} \\
\hline & & $0-15 \mathrm{~cm}$ & $15-30 \mathrm{~cm}$ & $0-15 \mathrm{~cm}$ & $15-30 \mathrm{~cm}$ & $0-15 \mathrm{~cm}$ & $15-30 \mathrm{~cm}$ & $0-15 \mathrm{~cm}$ & $15-30 \mathrm{~cm}$ \\
\hline 1 & Ceiba pentandra & $1.59 \mathrm{~b}$ & $1.36 \mathrm{c}$ & $287.31 \mathrm{a}$ & $270.95^{\mathrm{a}}$ & $25.95 b$ & $21.0^{b}$ & $109.30^{\mathrm{a}}$ & $96.00^{a}$ \\
\hline 2 & Artocarpus hirsutus & $2.38 \mathrm{a}$ & $2.25 \mathrm{a}$ & $266.78 b c$ & $240.95^{\mathrm{b}}$ & $40.74 a$ & $24.1^{\mathrm{a}}$ & $87.63^{b}$ & $79.20^{b}$ \\
\hline 3 & Grevillea robusta & $1.65 b$ & $1.52 b$ & $194.01 \mathrm{c}$ & $180.63^{\mathrm{c}}$ & $16.01 d$ & $12.36^{\mathrm{d}}$ & $54.93^{\mathrm{c}}$ & $51.32^{\mathrm{c}}$ \\
\hline \multirow[t]{6}{*}{4} & $\begin{array}{l}\text { Sterculia } \\
\text { companulata }\end{array}$ & $1.33 c$ & $1.20 \mathrm{c}$ & $270.95 b$ & $252.78^{b}$ & $20.83 c$ & $15.04^{\mathrm{c}}$ & $34.28^{\mathrm{d}}$ & $28.40^{d}$ \\
\hline & F significance & $*$ & $*$ & $*$ & $*$ & $*$ & $*$ & $*$ & $*$ \\
\hline & Tree species (SEm) & 0.05 & 0.05 & 0.28 & 0.28 & 0.18 & 0.16 & 0.17 & 0.17 \\
\hline & Depth (SEm) & 0.02 & 0.02 & 0.14 & 0.14 & 0.09 & 0.32 & 0.08 & 0.08 \\
\hline & $\mathrm{CD}$ & 0.12 & 0.09 & 3.50 & 2.48 & 1.44 & 1.02 & 1.42 & 0.35 \\
\hline & $\mathbf{C V}$ & 15.23 & 15.23 & 1.14 & 1.14 & 4.5 & 4.5 & 1.62 & 1.62 \\
\hline
\end{tabular}

*Significance at $5 \%$

Values in the parenthesis are standard deviation of the mean.

Values followed by same superscript in a column do not differ significantly (LSD, P, 0.05) 


\section{References}

Alem S, Tadesse, W. and Pavlis J., 2010, Evaluation of soil nutrients under Eucalyptus grandis plantation and adjacent sub-montane rain forest. Journal of Forest Research 21(4): 457460.

Aneesh, S., 2014, Biomass production and nutrient dynamics in a multipurpose tree based black pepper production system. MSc (For.) thesis, Kerala Agricultural University, Thrissur, $100 \mathrm{p}$.

Balloni, W. and Favilli, F., 1987, Effects of agricultural practices on physical, chemical and biological properties of soils: the effect of some agricultural practices on the biological soil fertility. In: Barth, H., L'Hermite, P. (eds.), Scientific Basis for Soil Protection in the European Community, Elsevier, London,pp.161-175.

Batjes, N. H., 1996, The total carbon and nitrogen in soils of the world. Eur. J. Soil Sci. 47: 151-163.

Bellamy, P. H., Loveland, P. J., Bradley, R. I., Lark, R. M. and Kirk, G. J.,200,Carbonlossesfromallsoilsacross EnglandandWales1978-2003.Nat.437: 245-248.

Brady, N. C. and Weil, R. R., 2008, The Nature and Properties of Soil (14 ${ }^{\text {th }}$ edition).Prentice Hall, New York, $58 \mathrm{p}$.

Chaturvedi, S. and Melkania, U., 2013, Soil organic carbon stock in mixed oak and mixed pine forest of Kumaon Himalaya. Indian Forester 139(3): 218-221.

Cobb, W. R., Will, R. E., Daniels, R. F. and Jacobson, M. A., 2008, Aboveground biomass and nutrient in four shortrotation woody crop species growing with different water and nutrient availabilities. For. Ecol. Manage.
255(12): 4032-4039.

Dalai, D.,1997, Productivity of grasses in relation to site quality in Pinus roxburghii plantations. M.Sc. Thesis, Dr. Y. S. Parmar University of Horticulture and Forestry, Nauni, Solan, India.74p.

Das, D. K. and Chaturvedi, O. P., 2003, Biomass production and nutrient distribution in an age series of Dalbergia sissoo Roxb. Plantations. Range Manage. Agroforest. 24(1): 2730.

Dilly, O., Bach, H.J., Buscot, F., Eschenbach, C., Kutsch, W.L., Middelhoff, U., Pritsch, K. and Munch, J.C., 2000. Characteristicsand energetic strategies of the rhizosphere in ecosystems of the Bornhöved Lake district. Appl. Soil Ecol. 15: 201-210.

Ekelund, F., Ronn, R.and Christensen, S., 2001, Distribution with depth of protozoa, bacteria and fungi in soil profiles from three Danish forest sites. Soil Biol.Biochem. 33: 475-481.

Fassbender, H. W., 1998, Long-term studies of soil fertility in cacao-shade tree agroforestry systems: results of 15 years of organic matter and nutrient research in Costa Rica. In: Schulte, A. and Ruhiyat, D. (eds.), Soils of Tropical Forest Ecosystems: Characteristics, Ecology and Management.

Gladstone, W. T. and Ledig, F. T., 1990, Reducing pressure on natural forests through high-yield forestry. For. Ecol. Manage. 35(1-2): 69-98.

Golinska, P. and Dahm, H., 2011, Occurrence of actinomycetes in forest soil.Dendrobiology 66: 3-13.

Gopikumar, K. 2000, Growth, biomass and decomposition pattern of selected agroforestry tree species. Indian $J$. For. 23(1): 61-66.

Ingram, J. S. I. and Fernandes, E. C. M., 2001, 
Managing carbon sequestration in soils: concepts and terminology. Agric. Ecosyst. Environ. 87(1):111-117.

IPCC [Intergovernmental Panel on Climate Change]. 2001. Annual Report 20002001. Intergovernmental Panel on Climate Change, Cambridge University Press, Cambridge, UK, $221 \mathrm{p}$.

Jackson, M.L., 1958, Soil Chemical Analysis. Prentice Hall of India private ltd.New Delhi, 498p.

Jackson, M. L., 1973, Soil chemical analysis. Printice Hall of India, New Delhi.

Jha, M. N., Pande, P. and Rathore R K., 1984, Soil fertility status under different tropical pine plantations. Indian Journal of Forestry 7(4): 287-290.

Kinsbursky, R. S., Degani, R., Baranes, G. and Steinberger, Y., 1990, Root microbial population dynamics in a soil profile under the canopy of the desert shrub Zygophyllum dumosum. J. Arid Environ. 19(3): 261-267.

Koranda, M., Kaiser, C., Fuchslueger, L., Kitzler, B., Sessitsch, A., Sophie Zechmeister-Boltenstern, S. and Richter, A., 2013,Seasonal variation in functional properties of microbial communities in beech forest soil. Soil Biol. Biochem. 60: 95-104.

Lal,R., 2005, Soil carbon sequestration in natural and managed tropical forest ecosystems. Environmental Services of Agroforestry Systems. First World Congress on Agroforestry, Orlando, Florida, USA, 27 June-2 July 2004, Vol. 21, pp. 1-30. Food Products Press.

Lin,H.S.,Kogelmann,W.,Walker,C.,Bruns,M. A.,2006,Soil moisture patterns in a forested catchment ;a hydropedological

Geoderma131,345-368.

Marschner, P. and Rengel, Z., 2007, Contributions of rhizosphere interactions to soil biological fertility.
In: Abbott, L.K., Murphy, D.V. (eds.), Soil biological fertility a key to sustainable land use in agriculture. Springer,Dordrecht, The Netherlands, pp.81-98.

Meliani, A. Bensoltane., K. and Mederbel., 2012, Microbial Diversity and Abundance in Soil: Related to Plant and Soil Type. Am. J. Plant Nutr. Fert. Technol. 2 (1): 10-18.

Pande, P. K., 2004, Temporal variations in soil nutrients under tropical plantations.Annals of Forestry 12(1): 29-37.

Post, W. and Kwon, K., 2000, Soil carbon sequestration and land-use change: processes and potential. Global Change Biol. 6: 317-328.

Prescott, C. E. and Vesterdal, L., 2013, Tree species effects on soils intemperate and boreal forests: Emerging themes and research needs. For. Ecol. Mgmt. 309: 1-3.

Raina, A. K. and Gupta, M. K., 2009, Soil characteristics in relation to vegetation and parent material under different forest covers in Kempty forest range, Uttrakhand. Indian Forester 135(3): 331-341.

Samrithika, T., 2014, Belowground architecture and carbon stocks of silver oak (Grevillea robusta A. Cunn.) trees. MSc (For.) thesis, Kerala Agricultural University, Thrissur, 150p.

Saravanan, J., Mohanraj, R.AND Dhnakumar, S.,2011, Carbon stocks in

Kolli forests, Eastern Ghats (India) with emphasis on aboveground biomass, litter, woody debris and soils. I ForestBio geosciences For. 4(2): 61-65.

Sharma, B., 1991, Studies on the relationship of soil physico-chemical properties with chirpine associations. M.Sc. Thesis, Dr. Y. S. Parmar UHF, Nauni, Solan (H.P.), India. 72p. 
Sharrow, S. H. and.Ismail. S., 2004, Carbonand nitrogen storage in agro forests, tree plantations and pastures in western Oregon, USA. Agroforest. Syst.60:123- 130.

Shilpkar, P., Shah, M. C., Modi K. R. AND PATEL, S. M,. 2010, Seasonalchanges in microbial community structure and nutrients content in rhizospheric soil of Aegle marmelos tree. Ann. For. Res. 53(2): 135-140.

Sturz, A. V. and Christie, B. R., 2003, Beneficial microbial allelopathies in the root zone: the management of soil quality and plant disease with rhizobacteria. Soil Tillage Research. 72: 107-123.

Subbiah, B. V. and Asija, G. L., 1956, A rapid procedure for estimation of the available nitrogen in soils. Current Science, 25:259-260.

Walkley, A. J. and Black, A.,1934, Estimation of soil organic carbon by chromic acid titration method. Soil Science, 37:2928.

Yuanyuan, S., Li, Z., Zhiying, W. and Shaoping, W., 2011, Dynamics of soilnutrient and microbial community of larch plantation. J. Northeast Forestry University. 39: 82-98.

\section{How to cite this article:}

Ramyashree, K. L., S. C. Kiran and Nagarajaiah, C. 2019. Studies on Physico Chemical Properties of Soil in Tree Arboretum of UAS GKVK Bengaluru, Karnataka, India. Int.J.Curr.Microbiol.App.Sci. 8(09): 1373-1381. doi: https://doi.org/10.20546/ijcmas.2019.809.158 